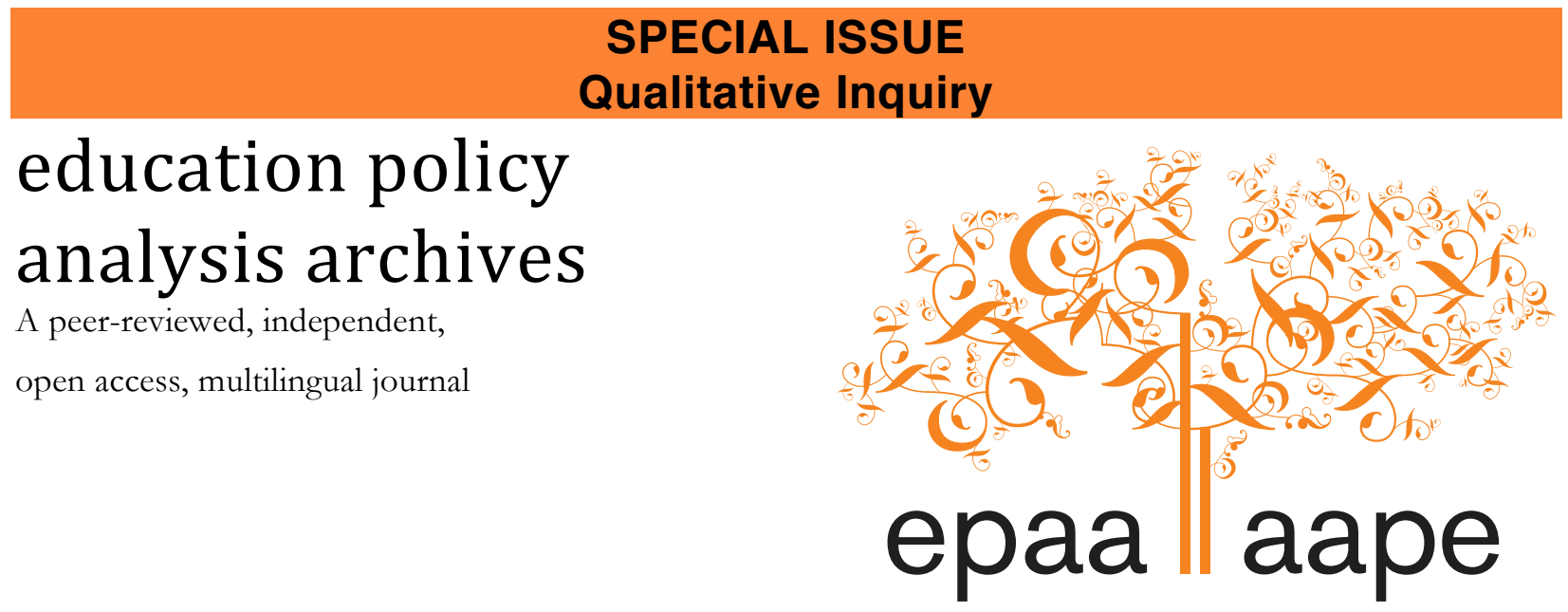

Arizona State University

\title{
What If Educational Inquiry Were Neither a Social Science Nor a Humanities Field? Revisiting Joseph Schawb's “The Practical" in the Aftermath of the Science Wars
}

\author{
Robert Donmoyer \\ University of San Diego \\ United States of America
}

Citation: Donmoyer, R. (2014). What If Educational Inquiry Were Neither a Social Science Nor a Humanities Field? Revisiting Joseph Schawb's “The Practical” in the Aftermath of the Science Wars. Education Policy Analysis Archives, 22 (8). http://dx.doi.org/10.14507/epaa.v22n8.2014. This article is part of EPAA/AAPE's Special Issue on Qualitative Inquiry.

\begin{abstract}
The recent debates about what constitutes scientific research in Education, on the one hand, and the so-called "paradigm wars" that got played out in the final quarter of the $20^{\text {th }}$ century, on the other, are more similar than different. At the center of both controversies was the relative worth of quantitative and qualitative research methods. Both controversies also distracted researchers' from addressing the substantive problems that plague schools and other educational organizations. This paper attempts to move the field beyond the debates of the past and similar debates that seem likely to occur in the future. Inspired, in large part, by Joseph Schwab's largely unheeded critique of the curriculum field in the late 1960s and early 1970s, the paper attempts to reconceptualize what inquiry in a field like Education should look like, as well as the role that quantitative, qualitative, and mixed-methods research could play in a re-conceptualized approach to inquiry.

Keywords: educational research; qualitative methods; Science Wars.

Journal website: http://epaa.asu.edu/ojs/

Facebook: /EPAAA

Manuscript received: 8/27/2013

Twitter:@epaa_aape

Revisions received: 10/6/2013

Accepted: 1/18/2014
\end{abstract}


¿Qué pasaría si la investigación educativa no fueran ni Ciencias Sociales ni tampoco un campo de las Humanidades? Revisitando Joseph Schwab, "The Practical” después de la guerra de las ciencias.

Resumen: Los recientes debates sobre lo que constituye la investigación científica en educación, por una parte, y los que acompañaron las llamadas " guerras de paradigmas" de los últimos 25 años del siglo 20, por el otro, son más similares que diferentes. En el centro de ambas controversias fue el valor relativo de los métodos de investigación cuantitativos y cualitativos. Ambas controversias distrajeron la atención de los investigadores para abordar los problemas de fondo que plagan escuelas y otros centros docentes. Este artículo trata de mover el campo más allá de los debates del pasado y debates similares que pareciera van a seguir ocurriendo. Inspirado, en gran parte, por la crítica (en gran medida ignorada) que Joseph Schwab realizó sobre el campo curricular a principios de la década de 1960 y a finales de 1970, este trabajo trata de volver a conceptualizar lo que la investigación en un campo como la educación debería ser, así como el papel que la investigación cuantitativa, cualitativos y de métodos mixtos podrían jugar en un enfoque re- conceptualizado de la investigación.

Palabras clave: investigación educativa; métodos cualitativos; guerra de las ciencias.

E se pesquisa educacional não eram nem ciências sociais, nem um campo das humanidades? Revisitando Joseph Schwab, “A Prática” após a guerra das ciências.

Resumo: Os recentes debates sobre o que constitui a pesquisa científica na educação, por um lado, e aqueles que acompanharam as "guerras paradigma" nos últimos 25 anos do século 20, por outro lado, são mais semelhantes do que diferentes. No cerne de ambas as disputas foi o valor relativo de métodos de pesquisa quantitativa e qualitativa. Ambas as controvérsias distraíram a atenção dos pesquisadores para resolver os problemas subjacentes que afligem as escolas e outras organizações educacionais. Este artigo tenta mover o campo para além dos debates do passado e que parece debates semelhantes continuarão acontecendo. Inspirado em grande parte, pela revisão (em grande parte ignorado) Joseph Schwab realizado em campo do currículo no início de 1960 e final de 1970 , este artigo tenta re-conceituar o que a pesquisa em um campo tão a educação deveria ser, e o papel que os métodos de pesquisa quantitativos, qualitativos e mistos poderiam jogar em uma perspectiva de investigação re-conceituada.

Palavras-chave: pesquisa educacional, os métodos qualitativos, guerras de ciência.

\section{Introduction}

What should be strikingly obvious to anyone who reflects on both the recent battles over what constitutes "scientific research in education" (National Research Council, 2002), the "paradigm wars" (Gage, 1989) about qualitative methods, and so-called positivist epistemology that were fought during the 1970s and 1980s (e.g. Lincoln \& Guba, 1985) is the amount of time and energy members of the educational research community spend engaging in internal methodological and epistemological debates. To be sure, these debates have had important consequences for members of the educational research community. The "paradigm wars," for example, helped legitimate the use of a wide variety of qualitative methods as well as the researchers who employed such methods. Conversely, the more recent debates about what constitutes scientific research in education (National Research Council, 2002) have had the effect of minimizing the use of qualitative methodology and narrowing researchers' methodological options, at least if researchers want to get their projects funded by the federal government and, also, increasingly, by private foundations. 
Indeed, government request for proposals (RFPs) now normally display a clear preference for experimental or quasi-experimental quantitative designs and relegate qualitative studies to a decidedly supporting role (e.g. Institute of Education Sciences, 2006). Even research and evaluation oriented foundations (e.g. Social Impact Exchange, 2012) often prefer the sort of randomized-trial designs that science-war combatant Grover Whitehurst (2003) championed as the new gold standard for educational inquiry.

Never-ending debates about research methods and theories of knowledge, however, also can be a distraction. I know a number of educational researchers, for example, who have built their careers almost exclusively around writing about research methods and the philosophical assumptions that support their use rather than actually using their touted research methods to study substantive concerns. As I think about what can feel like a never-ending (and seemingly unresolvable) debate about research methods and epistemological issues - a debate in which I often have been a willing participant (see, for example, Donmoyer, 1990, 1996, 1999, 2006)-I cannot help but think of what Joseph Schwab once wrote about the Curriculum Studies subfield within the larger field of Education.

In 1969 Schwab declared the Curriculum Studies field "moribund" and cited as evidence to support his claim "signs [that] consist of a large increase in the frequency of published papers and colloquia marked by a flight from the subject of the field" (p. 3, emphasis in the original). "The first and most important, though often least conspicuous, sign," according to Schwab,

is a flight of the field itself, a translocation of its problems and the solving of them from the nominal practitioners of the field to other men [and women]....A second flight is a flight upward, from discourse about the subject of the field to discourse about the discourse of the field, from use of principles and methods to talk about them. (p. 4)

Schwab also mentioned another indicator of flight from a field that is moribund: "a marked increase in eristic, contentious, and ad hominem debate" (p. 4).

I wonder: Do our re-occurring debates about methodology and the epistemological assumptions that support different methodological orientations-debates that frequently are quite "eristic, contentious, and ad hominem"- signal something similar to the "flight from the problems of the field" that Schwab observed in Curriculum Studies in 1969? Consequently, before we end up engaging in yet another version of the paradigm/science wars of the past, I want, in this paper, to step back and reconsider the basic frames both quantitative and qualitative (and, also, mixedmethods) researchers have been using to conceptualize the educational inquiry enterprise. In the process of doing this, the paper also will begin to conceptualize a quite different vision of what inquiry in a field like education might look like, a conceptualization that places deliberation about specific policy and practice decisions at the center of the inquiry process and recasts traditional qualitative, quantitative, and mixed-methods research in an important but, nonetheless, supporting role.

\section{Everything Old is New Again (Sort Of)}

\section{0th and 21st Century Battles Over Research Methods}

At first glance, the 21 st century science wars appear to be little more than reenactments of the so-called paradigm wars (Gage, 1989) that occurred in the educational research field during the 1970s and 80s. After all, both sets of skirmishes centered, to a large extent, on the relative virtues of quantitative and qualitative research methods. 
Those who started the paradigm wars, for instance, were fighting to legitimate the use of qualitative methods in the field of educational research. Some, like Miles and Huberman (1994), made the case for using qualitative methods on pragmatic grounds; others, like Lincoln and Guba (1985), embedded their methodological arguments in claims about the emergence of a new research paradigm that was built around a new and different epistemology. At the operational level, however, both sets of combatants focused on research methods, both claimed that traditional quantitative methods could not really tell policymakers and practitioners "what works" as quantitative researchers since Thorndike (1910) had assumed, and both argued that qualitative methods were required either as a supplement to (Miles \& Hubberman, 1994) or an alternative for (Lincoln \& Guba, 1985) traditional quantitative research designs.

Neither the insurgent qualitative researchers nor traditional quantitative researchers completely won the paradigm wars. Eventually, members of the field opted to embrace a version of "big-tent politics" (Donmoyer, 1999) and create space in the field for people with a wide variety of methodological proclivities. The ceasefire more-or-less ended in the first decade of the 21 st century, however, with the advent of the so-called science wars. Once again, the battle lines were drawn between qualitative and quantitative researchers.

In an invited address at the 2003 American Educational Research Association's (AERA) Annual Meeting, for example, Grover Whitehurst (2003), the newly appointed head of the newly created Institute of Education Sciences (IES), the federal agency charged with distributing funds to support educational research, proclaimed that quantitative experimental studies that randomly assigned research subjects to experimental and control groups were the new gold standard in educational inquiry. A year earlier, the National Research Council (2002) published Scientific Research in Education. That book, which was the work of a committee composed primarily of well-established members of the educational research field, made a more nuanced case for the relative superiority of quantitative methods.

Among other things, the authors of Scientific Research in Education acknowledged that, for a variety of reasons, it is not always feasible or prudent to implement the sort of randomized trial designs that were the federal government's new gold standard in educational inquiry. They also argued, however, that the invariant goal of "scientific research in education" is the creation of generalizable theory, and they suggested that theory (rather than the findings of any particular study or collection of studies) would be able to tell policymakers and practitioners "what works." Despite the caveats and qualifications, the methodological bottom line for those who led the scientific-research-in-education initiative for the National Research Council was not all that different than the bottom line articulated by Whitehurst (2003): "The bottom line is that experimentation has been shown to be feasible in education and related fields... and is still the single best methodological route to ferreting out systematic relations between actions and outcomes" (Feuer, Towne, \& Shavelson, 2002b, p. 8).

The authors of Scientific Research in Education did, in time, try to soften this bottom line a bit, especially in the two contributions the book's editors and an National Research Council staffer coauthored for a special issue of the Educational Researcher devoted to critiques of the book. In their lead article, for example, they acknowledged that "the rhetoric of scientifically based research in education seems to denigrate the legitimate role of qualitative methods in elucidating the complexities of teaching, learning, and schooling" (Feuer, Towne, \& Shavelson, 2002b, p. 8). They, then, went on to articulate what they believed to be the appropriate role for qualitative research:

When a problem is poorly understood and plausible hypotheses are scant—as is the case in many areas if education_qualitative methods such as ethnographies... and 
other tools like design experiments... are necessary to describe complex phenomena, generate theoretical models, and reframe questions. (p. 8).

Support for the use of qualitative methods also is a component of what appears to be an endorsement of mixed-methods research designs: "In keeping with our claim of the importance of attending to context in all scientific studies of education," Feuer, Towne, and Shavelson (2002b) wrote, "we believe that understanding causal processes and mechanism require close attention to contextual factors and that capturing these complexities typically requires qualitative modes of inquiry" (p. 8).

None of this was new, of course. Using qualitative methods for hypothesis and theory generation purposes was the sanctioned role for qualitative researchers to play prior to the paradigm wars. And, using qualitative methods to identify contextual factors that mitigate cause and effect generalizations and the theories that articulate them was endorsed by quantitative researchers during the earlier paradigm wars (see, for example, Cronbach, 1975; Gage, 1989). Such highly circumscribed endorsements of qualitative methods did not placate most qualitative research advocates during the paradigm wars of the past century, however, and they also did not dissuade qualitative researchers from criticizing Scientific Research in Education during the science wars that unfolded during the first decade of the 21 st century.

\section{An Important Distinction or a Distinction Without a Difference?}

There was, however, at least one potentially significant difference between the skirmishes about methods that occurred in our field during the final three decades of the 20th century and those that played out in the field during the first decade of the 21 st century: Those who made the 21 st century case for the relative superiority of quantitative methods and for a highly circumscribed role for qualitative research framed their comments as a discussion about the meaning of science rather than as a discussion about research methods per se. "Our attention to scientific educational research is not intended to exclude or minimize other forms of educational research and scholarship," Feuer, Towne, and Shavelson (2002a, p. 29) wrote in their rejoinder to postmodern scholar Elizabeth St. Pierre's (2002) critique of Scientific Research in Education. And, in their introductory essay for the special issue of Educational Researcher in which the St. Pierre critique appeared, Feuer, Towne, and Shavelson (2002b) articulated an important distinction between educational research generally and scientific educational research specifically. We focus on the latter. Though we assume unapologetically that scientific research is an endeavor that can uniquely contribute to greater understanding and improvement of education, we do not intend to minimize the significance of...nonscientific forms of study in education. (p. 8) Among other things, this new framing immunized those who employed it against charges of scientism (the ideology that assumes that science is the only valid source of knowledge). It also allowed those who employed it to endorse — or at least appear to endorse - the big-tent thinking that had actually ended the paradigm wars of the past: educational research that did not fit within the boundaries drawn by the authors of Scientific Research in Education was not necessarily bad research; it simply was not scientific research. The fact that AERA now has two sets of standards for reviewers of articles submitted to their journals for possible publication-one set for so-called scientific research and the other for non-scientific or what is referred to as humanities-based inquiry - is a testament to the impact of those who made the case for the relative superiority of quantitative over qualitative methods by reframing the methodological debate around the concept of science.

Most qualitative researchers were not mollified by the new version of big-tent politics articulated by the authors of Scientific Research in Education, however. Science, after all, has always been 
a contested concept. Anthropologist Clifford Geertz (1973/2000), for example, explicitly stated that the goal of his thick description-oriented form of ethnography was not the generation of theory (the central goal of scientific research, according to the authors of Scientific Research in Education), yet he also labeled what he and other cultural anthropologists did science (Geertz, 1973/2000).

Consequently, ethnographers and other qualitative researchers who used Geertz's ethnographic methods had little reason to accept the quite different conception of science promoted by the authors of Scientific Research in Education rather than the conception of science articulated by a wellregarded ethnographer.

Similarly, qualitative researchers influenced by feminist scholarship had no reason to prefer the particular conception of science articulated in Scientific Research in Education over the very different conception of science articulated by, say, feminist philosopher of science, Sandra Harding (1991). And, then, there is Betty St. Pierre $(2002,2011)$ and the postmodernists. To be sure, postmodernists undoubtedly would be more than happy to cede the science label to the authors of Scientific Research in Education (or to anyone else, for that matter). But they also would challenge the books narrative about what scientific research can accomplish and, in fact, most would turn that narrative on its head by focusing on the political and power dimensions of science, dimensions that have little if anything to do with the empirical data scientific studies generate (Donmoyer, 2005).

There are also more pragmatic reasons why some qualitative researchers have not accepted the Feuer, Towne, and Shavelson (2002a) distinction between "educational research generally and scientific educational research specifically" (p. 8) or the particular conception of science articulated in Scientific Research in Education (National Research Council, 2002). Scientific research is normally a synonym for fundable research. This is clearly the case with federal funding (Institute of Education Sciences, 2006; Whitehurst, 2002), but it is also increasingly the case for funding from private foundations (Social Impact Exchange, 2012) as well.

Finally - and, for me, in the context of this paper, most importantly - there is another type of pragmatic reason for rejecting the storyline about scientific research in education articulated in the book published by the National Research Council: What the authors of Scientific Research in Education promise cannot be delivered; theory simply cannot tell policymakers or practitioners what will work in the particular contexts they hope to influence.

\section{The Matters of Contextual Variation and Individual Idiosyncrasy}

The authors of Scientific Research in Education are correct when they claim that policymakers and many practitioners want educational researchers to identify cause/effect relationships that will tell them "what works" and allow them to fund, implement, and scale-up only effective educational programs and strategies. The authors also are correct when they claim that experimental research (using randomized assignment to experimental and control groups, if possible) is, in principle, the best vehicle for generating such knowledge. The problem, however, is that ideas that are correct in principle are not necessarily viable when principles get played out in reality. In the real world, contextual complexity and the idiosyncratic nature of individuals inevitably come into play. The importance of context and the idiosyncratic nature of human beings, in fact, were front and center in the case for qualitative methods made during the paradigm wars of the last century (see, for example, Lincoln and Guba's critique of the concept of causality in their 1985 book, Naturalistic Inquiry) and, also, in many critiques of Scientific Research in Education articulated in this century. (The inevitability of contextual and individual variation, for instance, is a foundational idea in the paper Fred Erickson has written for the special issue in which this paper appears.)

The authors of Scientific Research in Education were not completely oblivious to the problems created by contextual and individual variation. In fact, they acknowledged the problem of contextual 
variation and declared that the theories developed in education have to take contextual variation into account. Unfortunately, developing theories that adequately accommodate contextual variation and the idiosyncratic nature of individuals is easier said than done.

Ironically, it is the person to whom the authors of Scientific Research in Education dedicated their book, Lee Cronbach, who, over the course of his career, demonstrated the problem with the authors' solution to the contextual variation problem. In the 1950s, Cronbach (1957) was saying much the same thing about managing the contextual variation problem that the authors of Scientific Research in Education articulated in 2002. According to Cronbach, in the 1950s the field of educational psychology merely had to bring together what he referred to as "the two schools of scientific psychology"-i.e., the school that studied the effects of treatments on individuals and the school that documented personal characteristics and individual differences. Rather than asking about the effect of a treatment on people, in general, Cronbach argued, researchers needed to ask about the effect of a treatment on people with certain characteristics (or, to use Cronbach's term, certain aptitudes).

By the 1970s, however, after nearly two decades of trying to track down what Cronbach referred to as Aptitude X Treatment interaction (ATI) effects, he had revised his thinking: "An ATI result can be taken as a general conclusion, "Cronbach wrote in 1975, only if it is not in turn moderated by further variables. If Aptitude X Treatment X Sex interact, for example, then the Aptitude X Treatment effect does not tell the story. Once we attend to interactions, we enter a hall of mirrors that extends to infinity. However far we carry our analysis - to third order or fifth order or any other - untested interactions of still higher order can be envisioned (p. 119).

By the 1980s, Cronbach had moved even further away from the thinking he had articulated in the 1950s (and, also, the thinking articulated in Scientific Research in Education about this matter). In a book chapter published in 1982, for example, Cronbach was sounding more like a constructivist qualitative researcher than his earlier professional self. Among other things, he now claimed that social action was constructed not caused. He also compared researchers and decision makers who expected research, in time, to produce definitive knowledge about cause and effect generalizations to the characters in the Beckett (2004) play "Waiting for Godot," i.e., people who were waiting for something that never appeared.

Elsewhere, I have suggested that constructivist qualitative researchers' cavalier rejection of the concept of causality (see, for example, Lincoln \& Guba, 1985) was problematic. Even if the notion of causality is a fiction, I argued, it is a highly functional fiction in social life (Donmoyer, 2012); we would not, for example, be able to make social policy of any sort without at least positing the existence of cause and effect relationships. But claiming that the concept of causality is functional is not the same thing as claiming that scientific educational researchers will be able to develop theories about cause-effect relationships that will tell policymakers and practitioners, with any degree of certainty, what will work in a particular place and at a particular time. If our community continues to makes such promises, it may temporarily improve what the authors of Scientific Research in Education claim (not without justification) is the field's bad reputation within policymaker and practitioner communities. Unfortunately, cynicism about our field almost certainly will be even greater when even scientific educational researchers fail to do the impossible and policymakers and practitioners still find themselves "waiting for Godot."

\section{So, What's a Field Like Educational Research to Do?}

Educational researchers, then, would seem to be between the perennial rock and hard place when it comes to their relationship with the policy and practice communities. Policymakers and 
practitioners expect educational researchers to tell them "what works," yet researchers cannot really do this, at least not in the way and not to the degree that policymakers expect. Obviously, qualitatively oriented educational researchers can only document what appeared to have worked in a particular case or small number of cases and provide "working hypotheses" about what might work elsewhere (Lincoln \& Guba, 1985). But even quantitative researchers focused on producing the socalled "scientific" theories touted by the authors of Scientific Research in Education also will not succeed in playing the what-works game (National Research Council, 2002). Even if contemporary researchers could somehow generate theories that factored in all relevant individual differences and contextual contingencies - something Cronbach concluded was impossible to do-they would be left with theories that are too baroque and complex for policymakers and practitioners to use to guide their decision making.

Clearly, if the research community wants to avoid making promises it cannot fulfill—and if it wants to avoid engaging in more grand methodological debates in the future that obscure more than they reveal - there is a need to re-conceptualize the notion of inquiry for a field like Education. The work of Joseph Schwab $(1969,1971,1973)$ and, in particular, his notion of the practical provides a roadmap, of sorts, for this reconceptualization process.

\section{Revisiting Schwab's Notion of "The Practical"}

\section{Schwab on Theory}

When Schwab, in 1969, declared the curriculum field moribund, he attributed the curriculum field's moribund state to its "reliance on theory in an area where theory is partly inappropriate" (p. 1). His argument, which was developed further in two follow-up articles published in 1971 and 1973, was similar to the argument about the limits of theory that was just presented, though he added a few physical science examples to help make his point. "The constantly accelerating body of classical mechanics," Schwab wrote in 1969, "was the acceleration of a body in 'free' fall, fall in a perfect vacuum, and the general or theoretical rule formulated in classical mechanics is far from describing the fall of actual bodies in actual mediums" (p.11). Schwab (1969) also noted that

The rule that light varies inversely as the square of the distance holds exactly only for an imaginary point source of light. For real light sources of increasing expanse, the so-called law holds more and more approximately, and for very large sources it affords little or no useable information. (p. 11)

After providing examples from the physical sciences, Schwab noted: "What is true of the best of theories in the simplest sciences is true a fortiori in the social sciences" (p. 11). Schwab went on to explain why theoretical approximations are much more problematic in the social and behavioral sciences than they are in the physical sciences. The social and behavioral sciences, Schwab contended,

are marked by the coexistence of competing theories. There is not one theory of personality but twenty, representing at least six radically different choices of what is relevant and important in human behavior. There is not one theory of groups but several. There is not one theory of learning but half a dozen. All the social and behavioral sciences are marked by "schools," each distinguished by a different choice of principle of enquiry, each of which selects from the intimidating complexities of the subject matter the small fraction of the whole with which it can deal. (p. 13)

In short, implicit within different theories in the behavioral and social sciences are different a priori frames that determine what counts (and what gets counted). Behavioral and social science theories, in other words, are not just empirical. They also implicitly endorse particular ways of viewing the 
world and, in the process, value certain things over other things. Furthermore, we cannot conduct a critical experiment or, even, a series of critical experiments to determine which of a number of rival theories is correct because rival theories are framed in different ways and do not employ a common language. As a consequence, rival theories also implicitly endorse different criteria for assessing a theory's relative worth.

Schwab went on to propose an alternative to what he believed was the curriculum field's inappropriate fixation on theory. Could the alternative Schwab proposed for the curriculum field years ago be applied to the field of educational research today? That is the question I want to consider here.

\section{Schwab's Alternative}

Schwab's (1969) alternative entailed being eclectic and refocusing scholarly attention "from the theoretic to the practical. By eclectic," Schwab wrote,

I mean the arts by which unsystematic, uneasy, but usable focus on a body of problems is effected among diverse theories, each relevant to the problems in a different way. By the "practical" I do not mean the curbstone practicality of the mediocre administrator and the man on the street, for whom the practical means the easily achieved, familiar goals which can be reached by familiar means. I refer, rather, to a complex discipline, relatively unfamiliar to the academic and differing radically from the disciplines of the theoretic. (p. 1)

Schwab, here, is invoking a distinction that dates back to Aristotle. In Aristotelian terms, theory is about knowledge; the practical is about choice and action. Theory provides truth (which, in modern life, is determined empirically, albeit relative to the a priori frame that was employed to generate empirical findings); the practical is oriented toward making defensible decisions.

What Schwab (1969) means by the practical can probably be best understood by focusing on the method he recommends using to make defensible decisions about choice and action. Schwab refers to that method as deliberation and notes that

deliberation is complex and arduous. It treats both ends and means and must treat them as mutually determining one another. It must try to identify, with respect to both, what facts may be relevant. It must try to ascertain the relevant facts in the concrete case. It must try to identify the desiderata in the case. It must generate alternative solutions. It must make every effort to trace the branching pathways of consequences which may flow from each alternative and affect desiderata. It must then weigh alternatives and their costs and consequences against one another and choose, not the right alternative, for there is no such thing, but the best one. (pp. 2021, emphasis in original)

An example of deliberation. Schwab did not provide even a hypothetical example of deliberation in the real world, but philosopher of science Stephen Toulmin (1972) did. Toulmin provided his hypothetical example in the process of distinguishing between what happens in academic disciplines that are held together by a shared (but also limited) purpose and, consequently, a shared theoretical perspective, on the one hand, and public policy fields where different, and often conflicting, purposes come into play on a regular basis, on the other.

Toulmin (1972) noted that a group of engineers would likely agree on the optimal place for a community to build a dam in a particular area of the country precisely because they more than likely employ a shared theoretical framework. That is not, necessarily, where a board of community representatives charged with making policy decisions will decide to build the dam, however. The board cannot opt to build the dam where the engineers tell them it will collapse, of course, but 
before they decide on their optimal location, the board will want to consider and weigh a range of perspectives and criteria.

For example, board members undoubtedly would want to consider the community disruption that building a dam in certain places would cause and the price the community (or at least certain segments of the community) would pay in terms of social cohesion. They also, undoubtedly, would want to consider and factor into their decision cost. And, if the community representatives are elected representatives, they also almost certainly would want to weigh the impact of any decision the board makes on their re-election prospects. To adequately address some concerns, they may even want to consult with experts other than engineers, i.e. experts who view the world through different theoretical frames than the theoretical frame used by engineers. To the extent that the final decision was made intellectually through discussion and debate, rather than through the exercise of brute power, the community representatives would have engaged in at least a reasonable facsimile of what Schwab calls deliberation.

Other aspects of "the practical." There are a number of other aspects to Schwab's (1969) "complex discipline, relatively unfamiliar to the academic and differing radically from the disciplines of the theoretic" (p. 1). Schwab emphasizes, for example, that the practical is about incremental change and that the changes that are made must be carefully planned and so consciously coordinated "with what remains unchanged that the functioning of the whole remain coherent and unimpaired" (p.14).

Furthermore, the impetus for change is "identified frictions and failures" (Schwab, 1969, p. 16), not, as is so often the case today, some new theory, either from academia, the popular press, the growing cadre of professional reformers attempting to sell their wares to schools, or some combination of these sources of reform ideas. "Theory," Schwab wrote,

by being concerned with new things to do, is unconcerned with the successes and failures of present doings. Hence present failures, unless they coincide with what is repaired by the proposed innovations, go unnoticed-as do present successes. The practical, on the other hand, is directly and deliberately concerned with the diagnosis of ills. (pp. 16-17)

Undoubtedly, the thoughtful and student-oriented school counselor who complained, during my interview with him a few years ago, about his school district's propensity to promote "reforms du jour" would applaud at least this aspect of Schwab's notion of the practical. I suspect other counselors, teachers, and administrators in other districts with a propensity to embrace theoretically driven reforms in a seemingly mindless search of some sort of educational salvation also would join in the applause.

Summary. There are a number of other aspects to Schwab's conception of the practical that cannot be detailed here due to space considerations. Hopefully, enough has been said for readers to at least glimpse what the field of educational research would look like if it were reoriented around Schwab's notion of the practical and his method of deliberation.

If this would happen, for example, the sort of theory that so interested the authors of Scientific Research in Education would still matter, but it would no longer be expected to provide policymakers and practitioners definitive answers to their what-works question, something no theory, no matter how scientific it might be, can do. Theory would now function as a tool within the deliberation process about what to do about specific problems in specific situations. In that process, a number of theories reflecting a number of different concerns could provide a number of specific ways to frame the problem under consideration (Weiss, 1991). Theories also could suggest what possibly would happen if certain decisions were made and certain actions taken. 
There also would also be plenty for qualitative and mixed-methods researchers interested in contributing to the deliberation process to do. Their work can provide frames for focusing deliberation, but there is also another role that qualitative researchers, in particular, can play. Schwab noted that deliberation needs to address specific problems, as well as consider what proposed solutions would do to existing ways of doing business in schools. To do these things, those engaged in deliberation must have a reasonably close-up sense of what is happening in the contexts that their deliberation is focusing on. Schwab commented back in 1969 about how little was actually known about how certain subjects of the curriculum were actually taught. My experiences doing research in schools and helping teachers and administrators study what is happening in their classrooms and in the school and district outside their classrooms suggests that this is still the case for many, if not all, aspects of schooling.

For example, one of my colleagues recently talked with the associate superintendent in an urban school district about a Mexican-American high school student who was scheduled to repeat a course he had taken the previous year. Because he had already passed the course, any credits he would accrue by taking the course a second time would be useless in accumulating the number of credits required for him to become the first member of his extended family to graduate from high school. The assistant superintendent seemed truly mystified. "He should not be repeating a course he already took; how in the world did this happen?" the associate superintendent asked. My colleague and I, however, had been doing qualitative and mixed-methods research in this district for years and had seen a surprisingly large number of scheduling problems similar to this one in high schools throughout the district. Before the assistant superintendent and others (including members of the research community) could productively deliberate about how to improve the district's painfully high dropout rate, especially among Mexican-Americans, they would need specific information about this and other problems. Qualitative researchers are able to provide this sort of descriptive information, and mixed-methods designs can be used to assess how widespread this and other identified problems are.

So, there is still a role for traditional qualitative, quantitative, and mixed-methods researchers to play if educational inquiry is re-oriented around the notion of deliberation. It is also the case, however, that traditional researchers of all methodological stripes would play a less central role than they (and, also, policymakers and practitioners) currently envision researchers playing. Their role would no longer be to tell policymakers and practitioners "what works" and, consequently, what to do. Rather, their role would be to provide input into a process of deliberation.

Conceivably, researchers could sometimes lead deliberation processes, but such work is quite different and requires a different skill set than the work associated with—and skill set required to do-traditional forms of quantitative, qualitative, and/or mixed-methods research. The skill set is undoubtedly closer to a the skill set needed by a counselor engaged in group therapy than the skill set required to do traditional social science research, but even the counselor analogy is inadequate because group therapy normally is not oriented toward arriving at a group decision about what sort of collective action to pursue.

Undoubtedly many researchers will opt not to engage in the sort of retraining required to play a different role than the researcher role they currently play, and those that resist playing a new role and continue to do what they have always done may find it difficult to play more of a supporting role in educational decision making than the lead role assigned to researchers in the what-works plotline. Difficult as all of this might be, however, re-orienting the field of educational inquiry around Schwab's notion of "the practical" and the process of deliberation that is the fundamental methodology of "the practical" seems preferable to perpetuating the illusion that 
educational research can do what educational research will never be able to do, no matter how "scientific" it becomes.

\section{Caveats}

I would be remiss if, before concluding this paper, I did not at least acknowledge a number of caveats with respect to the proposal to reorient the educational research field around Schwab's notion of "the practical." Four caveats will be discussed here.

Caveat \#1. First, I need to acknowledge that the curriculum field never followed Schwab's lead away from the theoretical and toward Schwab's conception of the practical. The so-called curriculum reconceptualists who became influential in Curriculum Studies soon after Schwab articulated his conception of "the practical" (See, for example, Pinar, 1975), in fact, embraced the theoretical with a vengeance. To be sure, the theory they embraced was European social theory and not the sort of theory rooted in systematic empirical research touted by the authors of Scientific Research in Education. Nevertheless, the reconceptualists in Curriculum Studies consciously accelerated what Schwab saw as a problematic "flight from the subject of the field" (Schwab, 1969, p. 3) by refocusing the field's attention on theorizing (about either macro societal force or one's highly personal experiences) and explicitly away from ameliorating specific practical problems within schools and similar sorts of organizations.

Caveat \#2. Even if Schwab's ideas had been embraced by the curriculum studies field, it is unlikely the thinking that emerged from Curriculum Studies would be appealing to many advocates of scientific research in education. If my conversations with science-in-education partisans are at all representative, the push for scientific research in education was motivated as much by "physics envy" as by anything else. More often than not, scientific-research-in-education partisans appear desperate to achieve the sort of status that the academy gives to economists; most would even settle for the respect that sociologists receive. A deliberation-oriented conception of the field of educational inquiry adapted from a relatively low status field like Curriculum Studies, therefore, is not likely to generate much enthusiasm in certain circles of the educational research community.

The good news, however, is that there is at least one high-status field that is built around the notion of a specialized form or reasoning and decision making. That is the field of law (Levi, 1948). In a recent paper, for example, University of Virginia law professors Spellman \& Schauer (2012) wrote:

In the 1973 film The Paper Chase, the iconic Professor Kingsfield announced to his class of first year law students: "you teach yourself the law. I train your minds. You come in here with a skull full of mush, and if you survive, you'll leave thinking like a lawyer." In claiming to teach students to think like lawyers, Kingsfield echoed the assumptions of centuries of legal ideology. In the seventeenth century, the great English judge Edward Coke glorified the "artificial reason" of the law..., and from then until now lawyers and judges have believed that legal thinking and reasoning is different from ordinary thinking and reasoning, even from very good ordinary thinking and reasoning. Moreover, the difference, as Kingsfield emphasized, has long been thought to be one of process and not simply of content. It is not only that those with legal training know legal rules that laypeople do not. Rather, lawyers and judges are believed, at least by lawyers and judges, to employ techniques of argument, reasoning, and decision making that diverge from those of even expert non-lawyer reasoners and decision makers. (p.3)

The claim that legal reasoning is fundamentally different from the sort of reasoning engaged in by ordinary individuals outside of legal contexts has been challenged (see, for example, Schlegel, 1980), 
of course. That debate within the field of law is not important here, however. The relevant point here is that there is a high-status field within the academy that is built around what is at least believed to be a specialized form of thinking and decision making; consequently, there is at least one high-status precedent for focusing the field of educational research around a process like deliberation.

Caveat \#3. The law analogy, however, suggests a third caveat: While the field of law has a variety of legal forums that serve as venues for, and help structure, the process of legal reasoning, there are few comparable forums in the educational research field to structure the process of deliberation. Schwab, in his 1969 paper, in fact, called for

the establishment of new journals, and education of educators so that they can write for them and read them. The journals will be forums where possible problems of curriculum will be broached from many sources and heir possible importance debated from many points of view. They will be the stage for display of anticipatory solutions to problems, from a similar variety of sources. They will constitute deliberative assemblies in which problems and alternative solutions will be argued by representatives of all for the consideration of all and for the shaping of intelligent consensus. (p. 21)

The sorts of journals that Schwab envisioned back in 1969 have not been created even in the curriculum field, much less in the field of education, more generally. And even if they had been, Schwab noted that "such journals [would]...not [be] sufficient. They stand as only one concrete model of the kind of forum which is required" (p. 21).

Early in my career I did experiment with another kind of forum. I built an evaluation design around the notion of deliberation and received my first grant from the federal government to systematically study what happened when the model was implemented in an elementary school to evaluate the school's language arts program (Donmoyer, 1991). The model entailed assembling a stakeholder forum composed of some of the school's teachers and its principal; representatives of the school's parents, some of whom were supportive and some of whom were critical of the current program; and a representative from the district office that had been advocating curriculum and teaching strategies that were, to some extent, at least, antithetical to the practices employed in the school. Forum members explored a number of ways to frame the issues, and considered a wide array of evidence, including not only the school's standardized test scores but also the actual tests that generated the scores to determine whether the tests matched forum members' definitions of reading.

They also generated evidence by using a process that the model referred to as joint observation; joint observation entailed having two forum members who had decidedly different perspectives of the program being evaluated watch the same segment of teaching and, then, collaboratively attempt write a description and an assessment of what had been observed. At the end of the process, forum members attempted to reach consensus on a series of recommendations about the program.

The process turned out to be more difficult to implement than I had envisioned (it lived up to Schwab's claim that "deliberation is complex and arduous" (p. 21)), but it also produced results that were both interesting and promising (see Donmoyer, 1991). However, because I was an untenured assistant professor at the time and realized that Schwab's thinking was not being embraced by the curriculum or any other field, I opted not to continue to explore the evaluation-asdeliberation notion after this initial foray and, instead, conducted more conventional research studies using qualitative methods that had begun to be accepted in the field. In retrospect, I regret this decision, however much it might have made sense in terms of career-building. If I had further developed and experimented with a deliberation approach to evaluation, our field might have had at least one reasonably well established forum in which to engage in the deliberation process. 
More recently, I was exposed to another process that, while not precisely what Schwab meant when he talked about deliberation, had some of the elements of a deliberative process and, consequently, might be adapted to deliberations about how to resolve specific problems in education. That process was the talking circle process used by some Indigenous culture.

In Indigenous cultures, talking circles are used for a variety of purposes, everything from problem solving to healing. The process, as its name suggests, generally entails having participants sit in a circle. One person begins to speak, and when he or she is finished speaking, another person begins speaking. Each person can speak for as long as he or she wants. When it is his or her turn to speak, each person is free to comment on what another member of the circle has said, or the new speaker can introduce a new topic. The task of the other circle members is to listen carefully to what other members of the circle are saying. The assumption is that every member of the circle has something valuable to offer the group and, consequently, group members must attend to what is being said by everyone. When each person, in turn, has spoken, the process begins again. The process ends when circle members have nothing more to say.

The talking circles in which I participated were organized by members of the Cree Nation on a Reserve in Canada. I was involved because one of my doctoral students wanted to study thinking about leadership and leadership practices in an Indigenous views culture. Gaining access was more difficult than even I anticipated, and my Ph.D. student and I participated in a number of talking circles, some of which were about access questions and some of which were on other topics. After the dissertation was completed, the student, a key informant from the Indigenous culture, and I wrote a paper presented at the 2012 meeting of the American Educational Research Association in which reflected on the access experience and what it meant for Western researchers who wanted to study Indigenous cultures (Buchanan, Makokis, \& Donmoyer, 2012). We attempted to use the talking circle idea in writing the paper. Each of us wrote an entry and then passed it on to the other two members of the circle. The next two circle participants did the same, in turn, and we continued around the circle until none of us had anything to add.

Let me state again, a talking circle process is not precisely the same thing as Schwab's notion of deliberation. But to the extent that it articulates a wide range of perspectives from different sorts of individuals, it may be helpful to incorporate talking circle procedures into a deliberative process. The two examples I have gleaned from work during the early and later years of my own career hopefully will help readers get at least a glimpse of what forums in which deliberation might occur could look like. Of course, the fact that I had to rely on somewhat ancillary examples from my personal research agenda to illustrate the types of forums that will need to be developed in our field also suggests the monumental task that must be accomplished if the educational research field is to be re-oriented around the practice of what Schwab (1969) called deliberation.

Caveat \#4. A final caveat can be articulated as a question: Will participants in a deliberation process today and in the foreseeable future be willing — or even able - to engage in deliberation processes that are invariably "complex and arduous" (Schwab, 1969, p.3)? We live, after all, in an era when people are accustomed to digesting argumentation that takes only 140 characters to articulate and an era when Fox News and MSNBC provide news programming to feed rather than challenge a priori assumptions and biases. Will people who now expect relatively simple and unqualified knowledge about "what works" in schools be able to sustain interest in a deliberative process that inevitably will require an appreciation of the complexity of educational issues and the need for many qualifications and caveats? I must admit, I do not know the answer to this question, but I fear what the answer might be. 


\section{Conclusion}

Here I have suggested that thinking that Joseph Schwab $(1969,1971,1973)$ articulated more than four decades ago may provide a way to reorient the educational research field so that it can respond to the concerns and expectations of policymakers and practitioners without making promises that the educational research process can never fulfill. Is re-orienting the field around Schwab's notion of "the practical" and the process of deliberation a viable idea? Given the caveats articulated in the prior section, I must admit that the answer to this question is hardly obvious. Indeed, some of the caveats might even suggest that there is a rather glaring contradiction in this paper's argument: Schwab, after all, argued for incremental rather than dramatic change. Although the deliberation-based conception of educational articulated here still has a role for both traditional quantitative and qualitative research to play, as well as a place for the theories touted by the authors of Scientific Research in Education, it also recasts traditional forms of research and traditional research products in a secondary and supporting role. One could argue that a change that requires at least some researchers to acquire entirely new skill sets and expects everyone to rethink what educational research can and cannot do is hardly incremental.

On the other hand, educational research is hardly a well-established fixture in policymaking and practice-oriented decision making processes, and it seems downright foolhardy for members of our field, in an effort to acquire a modicum of influence, at least temporarily, to make promises that even the sort of scientific research in education touted by the authors of Scientific Research in Education (National Research Council, 2002) cannot conceivably fulfill. Such unfulfilled promise will eventually create even more cynicism about educational research and educational researchers than already exists among policymakers and practitioners.

Furthermore, it also seems foolhardy for schools to continue to embrace theory-based reforms du jour that all too often contribute to rather than solve problems. Finally, it would be truly unfortunate for educational researchers to engage in yet another round of methodological warfare that sidesteps or camouflages the bottom-line question about how educational research can actually contribute to decision making about educational policy and practice. Joseph Schwab at least offers an alternative; the only question is how implementable that alternative really is.

\section{References}

Beckett, S. (2004). Waiting for godot. Cambridge, UK and New York: Cambridge University Press. Buchanan, J., Makokis, P., \& Donmoyer, R. (2012). An access story: A talking circle-inspired discussion of what happened when a doctoral student decided to study an Indigenous group's approach to leadership. Paper presented at the annual meeting of the American Educational Research Association, Vancouver, BC.

Cronbach, L. (1957). The two disciplines of scientific psychology. American Psychologist, 12, 671-684. http://dx.doi.org/10.1037/h0043943

Cronbach, L. (1975). Beyond the two disciplines of scientific psychology. American Psychologist, 30, 116-127. http://dx.doi.org/10.1037/h0076829

Cronbach, L. (1982). Prudent aspirations of social inquiry. In Kruskal, W. (Ed.), The social sciences: Their nature and lines (pp. 42-54). Chicago: University of Chicago Press.

Donmoyer, R. (1990). Generalizability and the single case study. In Eisner, E. \& Peshkin, A. (Eds.), Qualitative research in education. New York: Teachers College Press. 
Donmoyer, R. (1991). Postpositivist evaluation: Give me a for instance. Educational Administration Quarterly, 27, 265-296. http://dx.doi.org/10.1177/0013161X91027003003

Donmoyer, R. (1996). Educational research in an era of paradigm proliferation: What is a journal editor to do? Educational Researcher, 25(2), 19-25.

Donmoyer, R. (1999). The continuing quest for a knowledge base, 1976-1998. In J. Murphy \& K. S. Louis (Eds.), The American Educational Research Association's handbook of research on educational administration (2nd ed.). San Francisco: Jossey Bass.

Donmoyer, R. (2005). Science as scriptwriters: How educational researchers influence public policy without ever producing definitive results. In B. Alexander, G. Anderson, \& B. Gallegos (Eds.), Performance Theories in Education. Mahwah, NJ: Lawrence, Erlbaum Associates, Inc.

Donmoyer, R. (2006). Take my Paradigm...please! The legacy of Kuhn's construct in educational research. The International Journal of Qualitative Studies in Education, 19(1), 11-34. http://dx.doi.org/10.1080/09518390500450177

Donmoyer, R. (2012). Can qualitative researchers answer policymakers' what-works question? Qualitative Inquiry, 18, 662-673. http://dx.doi.org/10.1177/1077800412454531

Feuer, M., Towne, L. \& Shavelson, R. (2002a). Reply to commentators on "Scientific culture and educational research," Educational Researcher, 31(8), 28-29. http://dx.doi.org/10.3102/0013189X031008028

Feuer, M., Towne, L. \& Shavelson, R. (2002b). Scientific culture and educational research. Educational Researcher, 31(8), 4-14. http://dx.doi.org/10.3102/0013189X031008004

Gage, N.L. (1989). The paradigm wars and their aftermath: A "historical" sketch of research on teaching since 1989. Educational Researcher, 18(7), 4-10.

Geertz, C. (1973/2000). The interpretation of cultures: Selected essays. New York: Basic Books.

Harding, S. (1991). Whose science? Whose knowledge? Thinking from women's lives. Ithaca, NY: Cornell University Press.

Institute of Education Sciences. (2006, April 7). Research grants request for applications (IESNCER-2007-01). Retrieved July 20, 2006 from www.ed.gov/about/ofices/list/ies/programs.html

Lincoln, Y. \& Guba, E. (1985). Naturalistic inquiry. Thousand Oaks, CA: Sage.

Levi, E. (1948). An introduction to legal reasoning. Chicago: University of Chicago Press.

Miles, M. \& Huberman, (1994). Analyzing qualitative data: An expanded Sourcebook. Thousand Oaks, CA: Sage Publications.

National Research Council. (2002). Scientific research in education. In R.J. Shavelson and L. Towne (Eds.), Committee on Scientific Principles for Education Research. Washington, D.C. National Academy.

Pinar, W. (Ed.). (1975). Curriculum theorizing: The reconceptualists. Berkeley, CA: McCutchan Publishing Corporation.

Schlegel, J. (1980). American legal realism and empirical social science: The singular case of Underhill Moore. Buffalo Law Review, 29, 195-303.

Schwab, J. (1969, November). The practical: A language for curriculum. The School Review, 78(1), 123. http://dx.doi.org/10.1086/442881

Schwab, J. (1971). The practical: Arts of the eclectic. The School Review, 79(4), 493-542. http://dx.doi.org/10.1086/442998

Schwab, J. (1973). The practical 3: Translation into curriculum. The School Review, 81(4), 501-522. http://dx.doi.org/10.1086/443100

Social Impact Exchange. (2012). Social impact exchange selection process. Retrieved March 30, 2013 from www.socialimpactexchange.org/page/selection-process. 
Spellman, B. \& Schauer, F. (2012). Legal reasoning. http://ssrn.com/abstract=2000788. Retrieved April 1, 2012.

St. Pierre, E. (2002). Science rejects postmodernism. Educational Researcher, 31(8), 25-27. http://dx.doi.org/10.3102/0013189X031008025

St Pierre, E. (2011). Post-qualitative research: The critique and the coming after. In Denzin, N. and Lincoln, Y. (Eds.), The Handbook of Qualitative Research, $4^{\text {th }}$ Edition (pp. 611-635). Thousand Oaks: Sage.

Thorndike, E. L. (1910). The contribution of psychology to education. The Journal of Educational Psychology, 1(1), 5-12. http://dx.doi.org/10.1037/h0070113

Toulmin, S. (1972). Human understanding: The collective use and evolution of concepts. Princeton, NJ: Princeton University Press.

Weiss, C. (1991). Knowledge creep and decision accretion. In Anderson, D. and Biddle, B. (Eds.), Knowledge for policy: Improving education through research (pp. 173-182). London: Falmer Press.

Whitehurst, G. (2003, April). The Institute of Education Sciences. New wine in new bottles. Invited Address to the annual meeting of the American Educational Research Association, Chicago, IL. 


\title{
About the Author
}

Robert Donmoyer

Professor

University of San Diego

donmoyer@sandiego.edu

Robert Donmoyer is presently is Professor of Leadership Studies at the University of San Diego.

Previously he served as a professor and the director of School of Educational Policy and Leadership at the Ohio State University. He has written extensively about qualitative research and evaluation methods, educational leadership and reform, and the philosophical issues that ground research practice. During the past five years, he has received two multi-year research grants from the federal government as well as research funding from the Ball Foundation.

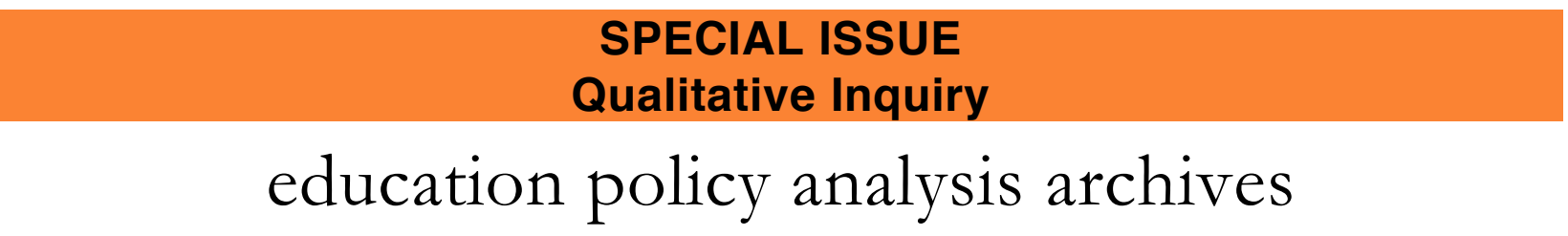

\author{
Volume 22 Number $8 \quad$ February $17^{\text {th }}, 2014$
}

ISSN 1068-2341

\begin{abstract}
(a)
SOMEREIGHISRESERVED Readers are free to copy, display, and distribute this article, as long as the work is attributed to the author(s) and Education Policy Analysis Archives, it is distributed for noncommercial purposes only, and no alteration or transformation is made in the work. More details of this Creative Commons license are available at http://creativecommons.org/licenses/by-nc-sa/3.0/. All other uses must be approved by the author(s) or EPAA. EPAA is published by the Mary Lou Fulton Institute and Graduate School of Education at Arizona State University Articles are indexed in CIRC (Clasificación Integrada de Revistas Científicas, Spain), DIALNET (Spain), Directory of Open Access Journals, EBSCO Education Research Complete, ERIC, Education Full Text (H.W. Wilson), QUALIS A2 (Brazil), SCImago Journal Rank; SCOPUS, SOCOLAR (China).
\end{abstract}

Please contribute commentaries at http://epaa.info/wordpress/ and send errata notes to Gustavo E. Fischman fischman@asu.edu

Join EPAA's Facebook community at https://www.facebook.com/EPAAAAPE, Twitter feed @epaa_aape, and Academia.edu page at: http://asu.academia.edu/EPAAAAPE 


\section{education policy analysis archives editorial board}

Editor Gustavo E. Fischman (Arizona State University)

Associate Editors: Audrey Amrein-Beardsley (Arizona State University) Rick Mintrop, (University of California, Berkeley) Jeanne M. Powers (Arizona State University)

Jessica Allen University of Colorado, Boulder

Gary Anderson New York University

Michael W. Apple University of Wisconsin, Madison

Angela Arzubiaga Arizona State University

David C. Berliner Arizona State University

Robert Bickel Marshall University

Henry Braun Boston College

Eric Camburn University of Wisconsin, Madison

Wendy C. Chi* University of Colorado, Boulder

Casey Cobb University of Connecticut

Arnold Danzig Arizona State University

Antonia Darder University of Illinois, UrbanaChampaign

Linda Darling-Hammond Stanford University

Chad d'Entremont Strategies for Children

John Diamond Harvard University

Tara Donahue Learning Point Associates

Sherman Dorn University of South Florida

Christopher Joseph Frey Bowling Green State University

Melissa Lynn Freeman* Adams State College

Amy Garrett Dikkers University of Minnesota

Gene V Glass Arizona State University

Ronald Glass University of California, Santa Cruz

Harvey Goldstein Bristol University

Jacob P. K. Gross Indiana University

Eric M. Haas WestEd

Kimberly Joy Howard* University of Southern California

Aimee Howley Ohio University

Craig Howley Ohio University

Steve Klees University of Maryland

Jaekyung Lee SUNY Buffalo
Christopher Lubienski University of Illinois, UrbanaChampaign

Sarah Lubienski University of Illinois, UrbanaChampaign

Samuel R. Lucas University of California, Berkeley

Maria Martinez-Coslo University of Texas, Arlington

William Mathis University of Colorado, Boulder

Tristan McCowan Institute of Education, London

Heinrich Mintrop University of California, Berkeley

Michele S. Moses University of Colorado, Boulder

Julianne Moss University of Melbourne

Sharon Nichols University of Texas, San Antonio

Noga O'Connor University of Iowa

João Paraskveva University of Massachusetts, Dartmouth

Laurence Parker University of Illinois, UrbanaChampaign

Susan L. Robertson Bristol University

John Rogers University of California, Los Angeles

A. G. Rud Purdue University

Felicia C. Sanders The Pennsylvania State University Janelle Scott University of California, Berkeley

Kimberly Scott Arizona State University

Dorothy Shipps Baruch College/CUNY

Maria Teresa Tatto Michigan State University

Larisa Warhol University of Connecticut

Cally Waite Social Science Research Council

John Weathers University of Colorado, Colorado Springs

Kevin Welner University of Colorado, Boulder

Ed Wiley University of Colorado, Boulder

Terrence G. Wiley Arizona State University

John Willinsky Stanford University

Kyo Yamashiro University of California, Los Angeles

* Members of the New Scholars Board 


\section{archivos analíticos de políticas educativas consejo editorial}

Editor: Gustavo E. Fischman (Arizona State University)

Editores. Asociados Alejandro Canales (UNAM) y Jesús Romero Morante (Universidad de Cantabria)

Armando Alcántara Santuario Instituto de Investigaciones sobre la Universidad y la Educación, UNAM México

Claudio Almonacid Universidad Metropolitana de Ciencias de la Educación, Chile

Pilar Arnaiz Sánchez Universidad de Murcia, España

Xavier Besalú Costa Universitat de Girona, España Jose Joaquin Brunner Universidad Diego Portales, Chile

Damián Canales Sánchez Instituto Nacional para la Evaluación de la Educación, México

María Caridad García Universidad Católica del Norte, Chile

Raimundo Cuesta Fernández IES Fray Luis de León, España

Marco Antonio Delgado Fuentes Universidad Iberoamericana, México

Inés Dussel FLACSO, Argentina

Rafael Feito Alonso Universidad Complutense de Madrid, España

Pedro Flores Crespo Universidad Iberoamericana, México

Verónica García Martínez Universidad Juárez Autónoma de Tabasco, México

Francisco F. García Pérez Universidad de Sevilla, España

Edna Luna Serrano Universidad Autónoma de Baja California, México

Alma Maldonado Departamento de Investigaciones Educativas, Centro de Investigación y de Estudios Avanzados, México

Alejandro Márquez Jiménez Instituto de Investigaciones sobre la Universidad y la Educación, UNAM México

José Felipe Martínez Fernández University of California Los Angeles, USA
Fanni Muñoz Pontificia Universidad Católica de Perú

Imanol Ordorika Instituto de Investigaciones

Economicas - UNAM, México

Maria Cristina Parra Sandoval Universidad de Zulia, Venezuela

Miguel A. Pereyra Universidad de Granada, España

Monica Pini Universidad Nacional de San Martín, Argentina

Paula Razquin UNESCO, Francia

Ignacio Rivas Flores Universidad de Málaga, España

Daniel Schugurensky Universidad de Toronto-Ontario Institute of Studies in Education, Canadá

Orlando Pulido Chaves Universidad Pedagógica Nacional, Colombia

José Gregorio Rodríguez Universidad Nacional de Colombia

Miriam Rodríguez Vargas Universidad Autónoma de Tamaulipas, México

Mario Rueda Beltrán Instituto de Investigaciones sobre la Universidad y la Educación, UNAM México

José Luis San Fabián Maroto Universidad de Oviedo, España

Yengny Marisol Silva Laya Universidad Iberoamericana, México

Aida Terrón Bañuelos Universidad de Oviedo, España

Jurjo Torres Santomé Universidad de la Coruña, España

Antoni Verger Planells University of Amsterdam, Holanda

Mario Yapu Universidad Para la Investigación Estratégica, Bolivia 


\title{
arquivos analíticos de políticas educativas conselho editorial
}

\author{
Editor: Gustavo E. Fischman (Arizona State University) \\ Editores Associados: Rosa Maria Bueno Fisher e Luis A. Gandin
}

(Universidade Federal do Rio Grande do Sul)

Dalila Andrade de Oliveira Universidade Federal de Minas Gerais, Brasil

Paulo Carrano Universidade Federal Fluminense, Brasil

Alicia Maria Catalano de Bonamino Pontificia Universidade Católica-Rio, Brasil

Fabiana de Amorim Marcello Universidade Luterana do Brasil, Canoas, Brasil

Alexandre Fernandez Vaz Universidade Federal de Santa Catarina, Brasil

Gaudêncio Frigotto Universidade do Estado do Rio de Janeiro, Brasil

Alfredo M Gomes Universidade Federal de Pernambuco, Brasil

Petronilha Beatriz Gonçalves e Silva Universidade Federal de São Carlos, Brasil

Nadja Herman Pontificia Universidade Católica -Rio Grande do Sul, Brasil

José Machado Pais Instituto de Ciências Sociais da Universidade de Lisboa, Portugal

Wenceslao Machado de Oliveira Jr. Universidade Estadual de Campinas, Brasil
Jefferson Mainardes Universidade Estadual de Ponta Grossa, Brasil

Luciano Mendes de Faria Filho Universidade Federal de Minas Gerais, Brasil

Lia Raquel Moreira Oliveira Universidade do Minho, Portugal

Belmira Oliveira Bueno Universidade de São Paulo, Brasil

António Teodoro Universidade Lusófona, Portugal

Pia L. Wong California State University Sacramento, U.S.A

Sandra Regina Sales Universidade Federal Rural do Rio de Janeiro, Brasil

Elba Siqueira Sá Barreto Fundação Carlos Chagas, Brasil

Manuela Terrasêca Universidade do Porto, Portugal

Robert Verhine Universidade Federal da Bahia, Brasil

Antônio A. S. Zuin Universidade Federal de São Carlos, Brasil 